UDC 332; DOI 10.18551/rjoas.2022-01.19

\title{
SUSTAINABILITY ANALYSIS OF THE ECONOMY OF PALM OIL PLASMA FARMERS IN SUNGAI LILIN DISTRICT OF MUSI BANYUASIN REGENCY, INDONESIA
}

\author{
Rospiani Destiya*, Lifianthi, Wulan Sari Dwi \\ Master's Program of Agribusiness, Faculty of Agriculture, University of Sriwijaya, Indonesia \\ *E-mail: destiyarospianidr@gmail.com
}

\begin{abstract}
Agriculture in Indonesia, especially oil palm plantations, strongly supports for Sustainable Agriculture by implementing Indonesian Sustainable Palm Oil (ISPO). One of the pillars of Sustainable Agriculture is the economy of oil palm farmers which is a financial aspect to see the form of changes in production value, variable costs, and farmers' income. Because oil palm plantations is a mainstay commodity in the plantation sub-sector. This study aims to analyze the sustainability of the income received by oil palm plasma smallholders. The research was conducted in Sungai Lilin District, Musi Banyuasin Regency. The study took a sample of $10 \%$ of the total population, whose are 72 oil palm plasma farmers in 2020-2021. The study used a survey method with direct interviews with respondents. The results showed that the level of sustainability in the production and income of oil palm plasma farmers was in the low criteria with the income of oil palm farming on plasma farmers was IDR. $6,899,141.95 / \mathrm{Ha} /$ Year.
\end{abstract}

\section{KEY WORDS}

Income, plasma smallholders, oil palm, sustainable agriculture, farming.

Sustainable agriculture is the implementation of the concept of sustainable development in the agricultural sector. The concept of sustainable agriculture is based on three pillars: economic, social, and ecology. True sustainable agriculture is one that is economically sustainable which is achieved by using less energy. Based on Indonesia's exports, exports of agricultural products continued to increase in 2019 by 5.29 percent despite the Covid-19 conditions (Central Bureau of Statistics, 2020).

Oil palm plantations are one of the pillars and hope in the Indonesian economy because oil palm is also one of the mainstay commodities in the plantation sub-sector. This can be seen from the production of palm oil (CPO) in 2019 is estimated to increase by 12.92 percent compared to 2018 to 48.42 million tons. Currently, cooking oil is the main absorber of domestic oil consumption, reaching 70 percent of the amount marketed domestically (Directorate General of Plantations, 2015).

However, the fact is that oil palm production in Indonesia does not always increase even though the area of oil palm plantations in Indonesia increases every year. This is inseparable from several problems found in the field. The problems that occur in oil palm plantations can be seen from the financial and non-financial aspects. The financial aspect is an aspect that looks at the changes that may occur in the form of changes in production value and variable costs, while the non-financial aspect will look at the market, technical, management and legal, economic and social aspects, as well as the environment which are directly related to efforts to carry out sustainability in oil palm plantations in Indonesia.

In 2018-2019 the area of oil palm plantations in Musi Banyuasin Regency is still the largest district in South Sumatra Province with an area of 356,131 $\mathrm{Ha}$ and 314,442 $\mathrm{Ha}$. Therefore, this problem is important to be investigated further in an effort to improve the development of community welfare which makes oil palm a regional superior commodity. Sungai Lilin Subdistrict is the seventh largest producer of palm oil in Musi Banyuasin Regency with a total production of 17,516 tons and a land area of 1,450 $\mathrm{Ha}$ in 2019 . Furthermore, the commodity of oil palm is one of the regional superior commodities that must continue to be improved because it involves the livelihoods of local people.

There are various problems in oil palm plantations, especially in Sungai Lilin District, 
Musi Banyuasin Regency starting from low production and declining in 2016 by 19,272 tons and in 2017 by 17,516, unstable income due to price fluctuations in 2016 the price of FFB was around IDR. 1447.3, and the FFB price was IDR. 1335.5 in 2017 (Rospiani, 2018), the difficulty of accessing capital, the lack of active institutions such as the Oil Palm Plantation Cooperative, the absence of legal power over plantations, to the lack of knowledge and information about environmentally friendly and sustainable plantation management.

It is suspected that the income received by oil palm plasma farmers in Sungai Lilin District, Musi Banyuasin Regency is low. So researchers are interested in conducting a study on sustainability analysis on the income of oil palm plasma farmers in Sungai Lilin District, Musi Banyuasin Regency, which is expected to be input in efforts to develop farming that can be felt equally by farmers, institutions, and companies.

\section{METHODS OF RESEARCH}

This research was conducted on oil palm farming in Sungai Lilin District, Musi Banyuasin Regency. The research location was chosen purposively with the consideration that Sungai Lilin District, Musi Banyuasin Regency is one of the sub-districts that on average are smallholders of oil palm in South Sumatra Province. In addition, Musi Banyuasin Regency has the largest oil palm plantation area in South Sumatra.

The method used in this study is a survey method that takes samples from the population that represent the overall characteristics of the population by using questionnaires and direct interviews with plasma farmer respondents who cultivate oil palm in Sungai Lilin District, Musi Banyuasin Regency.

The sampling method used in this study is the Simple Random Sampling technique. Simple Random Sampling method was used to determine the sample of plasma farmers, where in this method, sampling was carried out randomly because based on the variables to be studied the population of farmers in Sungai Lilin District, namely Sumber Rezeki Village and Suka Makmur Village were homogeneous, meaning that they had the same probability of be the research sample. The total population of tidal rice farmers is 720 population. The sample is part or representative of the population studied. If the number of respondents is less than 100, all samples are taken so that the research is a population study. Meanwhile, if the number of respondents is more than 100 , then the sampling is $10 \%-15 \%$ or $20 \%-25 \%$ (Arikunto, 2002). Based on this opinion, then the sampling in this study is $10 \%$ of the existing population, because the total population exceeds 100, namely 720 families of plasma farmers. Means $720 \times 10 \% / 100=72$ Plasma Farmers.

The method of data collection in the study was carried out by means of observation or field observations to determine the social, economic and environmental conditions in the processing of oil palm plantations. In-depth interviews to find out the stages of processing oil palm plantations, as well as the problems faced in the processing of oil palm plantations.with farmers in Sumber Rezeki and Suka Makmur villages based on a list of questions (questionnaires), while secondary data were obtained from various agencies related to the problem being studied, such as village officials, Plantation Service, Agricultural Extension, Central Statistics Agency (BPS), sub-district government and other related institutions or agencies, as well as from previous research that is related to the problem being studied. Then, archival records such as institutional data, middlemen or middlemen, location maps, image documentation and others. Data obtained from the field was processed in tabulation and then continued with descriptive statistical analysis, namely by describing the results obtained from the field in the form of a systematic description.

The indicators are guided by the principles and criteria of Indonesian Sustainable Palm Oil (ISPO) for plasma plantations in accordance with Minister of Agriculture Regulation No. 38 of 2020 dated November 16, 2020 regarding the implementation of the certification system for Indonesia's sustainable oil palm plantations in the economic dimension will use 7 (seven) indicators, including: land tenure or legality; labor potential; farmers' products; availability of agricultural input materials; production, financial income/profit ( $\mathrm{r} / \mathrm{c}$ ratio); interest in farming; availability of credit or working capital. 
For each indicator measurement, each dimension uses an ordinal measurement scale, with a vulnerable score ranging from 1 (one) to 3 (three) which means starting from a score of 3 for high criteria, 2 for medium criteria and 1 for low criteria.

Table 1 - Percentage of Sustainability Index Value

\begin{tabular}{ll}
\hline Index Value & Category \\
\hline $0 \%-25 \%$ & Bad \\
$25.01 \%-50 \%$ & Not enough \\
$50.01 \%-75 \%$ & Enough \\
$75.01 \%-100 \%$ & Good \\
\hline
\end{tabular}

Source: Nurmalina, R. 2008. Journal of Agro-Economy, Bogor Agricultural Institute.

Next to answer the second research objective, this is to calculate the income received by oil palm plasma farmers in Sungai Lilin District, Musi Banyuasin Regency by calculating the net income obtained by subtracting the overall revenue from the total cost, with the formula:

$$
\begin{gathered}
\text { TR }=\text { Py. Y } \\
\pi=P n-B T
\end{gathered}
$$

Where: $\pi=$ Income; $\mathrm{TR}=$ Total Revenue; $\mathrm{TC}=$ Total Cost .

\section{RESULTS AND DISCUSSION}

Plasma farmers in Sumber Rezeki Village and Suka Makmur Village, Sungai Lilin Subdistrict, Musi Banyuasin Regency are very dependent on oil palm farming for their livelihood. Therefore, the government implements Indonesia Sustainable Palm Oil (ISPO) which is a guidance sustainable palm oil development, as well as a commitment to implementing various relevant laws and regulations applicable in Indonesia, especially for oil palm plasma smallholders. according to the Regulation of the Minister of Agriculture No. 38 of 2020 dated November 16, 2020 regarding the implementation of the certification system for Indonesian sustainable oil palm plantations in the economic dimension will use 7 (seven) indicators, including: (1)Land tenure or plantation legality, (2) Labor potential, (3) Price stability of farmers' production or pricing, (4) Land productivity, financial income/profit (R/C ratio), (5) Interest in farming, (6 ) Availability of agricultural input materials, (7) Availability of business credit.

Table 2 - Parameters of Sustainability Indicators on Economic Dimensions of Oil Palm Smallholders in Indonesia: Sungai Lilin District, Musi Banyuasin Regency

\begin{tabular}{llll}
\hline No & Parameter & Score & Criteria \\
\hline 1 & Land tenure or garden legality & 3 & Tall \\
2 & Labor potential & 2 & Currently \\
3 & Stability of prices for farmers' products or price fixing & 1 & Low \\
4 & Productivity, financial income/profit (R/C ratio) & 1 & Low \\
5 & Interest in farming & 1 & Low \\
6 & Availability of agricultural input materials & 2 & Currently \\
7 & Availability of business credit & 2 & Currently \\
\hline & Average & 1.7 & Currently \\
\hline
\end{tabular}

Source: Primary data processed (2021).

The economic dimension refers to the calculation of profit and loss by maximizing income but still maintaining and maintaining assets that produce useful outputs including manufacturing, natural, human and social capital. The assets that are maintained will ensure stability and long-term output growth in sustainable farming.

International Institute for Sustainable Development (2014), made several criteria for the sustainability of the economic dimension, including: First, a written contract between a buyer 
and a seller, which means the criteria for making a contract with a trader. Second, the living wage means that this standard requires a minimum wage level that covers basic human needs, as defined locally by public authorities. Third, minimum wages mean requirements related to compliance with local minimum wage laws as defined by local, regional or national laws to be paid to workers in certified or verified operations. Fourth, the premium is part of the standard which must be above the conventional price of the product required for the producer. Fifth, the economic aspect is the aspect that underlies all activities related to the motive of getting money and using it as payment by farmers to obtain resources for their survival. Anything that guarantees the fulfillment of the necessities of life, even provides opportunities or has the potential to generate income. In this study, the economic dimension will use 7 (seven) indicators, including:

Land tenure or legality indicators: This indicator will look at the legal evidence of land ownership, whether it is the availability of land certificates, land sales and purchase deeds, girik and other proof of land ownership. So that farmers can overcome problems such as land disputes and other disputes. Oil palm smallholders in Sungai Lilin District, Musi Banyuasin Regency are included in the high criteria with a score of 3 because the average legality of the land for oil palm plantations is legal and has proof of certificate. The average land area for oil palm plantations is 2 ha per family head of oil palm smallholders.

Labor potential indicator: This indicator will look at the availability of labor in the area which will certainly affect the cost of processing smallholder oil palm plantations. In this case, oil palm plasma farmers in Sungai Lilin Subdistrict, Musi Banyuasin Regency are included in the moderate criteria with a score of 2 because usually workers are used, namely from outside the family but it is not difficult to find labor around the plantation because oil palm is the main livelihood in Sungai Lilin District. Musi Banyuasin Regency. Labor commonly used is at the time of planting, fertilizing, maintenance such as spraying HPT and trimming the midrib, as well as transporting FFB at harvest.

Indicators of price stability for farmers' produce: Stable prices and high exchange rates at harvest will be important factors that motivate farmers to manage oil palm plantations. In addition, with market stability, it can be seen that market access or opportunities faced by farmers in the research area can be seen. In this indicator, smallholder oil palm farmers in Sungai Lilin Subdistrict, Musi Banyuasin Regency are included in the low criteria with a score of 1 due to the instability of oil palm prices in Indonesia. In addition, oil palm in Sungai Lilin Sub-district, Musi Banyuasin Regency has just been replanted and has only started production in 2020, so the price of FFB for palm oil is still low because oil palm has not yet entered the productive age of oil palm.

Indicator Availability of agricultural input materials: When the area has sufficient availability of agricultural inputs, farmers will find it easier to manage their farming. So it is hoped that the processing of oil palm plantations can be carried out in a sustainable manner. In this case, oil palm plasma farmers in Sungai Lilin District, Musi Banyuasin Regency are included in the moderate criteria with a score of 2 because there are many business partners in agriculture, especially oil palm and oil palm companies that can supply agricultural input materials needed for oil palm plasma smallholders in the sub-district. Sungai Lilin, Musi Banyuasin Regency.

Interest in farming indicators: This indicator will look at farmers' interest in farming, such as whether farmers prefer to be farm laborers or outside of farming. In this indicator, oil palm plasma smallholders in Sungai Lilin District, Musi Banyuasin Regency are included in the low criteria with a score of 1 because according to the results of interviews with oil palm plasma farmers in Sungai Lilin District, Musi Banyuasin Regency, many farmers do not focus on farming and work outside of oil palm farming such as rubber and non-agricultural such as civil servants and traders. The demand for farming from youth in Sungai Lilin Subdistrict, Musi Banyuasin Regency is very low because the children of oil palm plasma farmers on average don't want to work as oil palm plasma farmers and prefer to work as office workers.

Indicator of availability of credit or business capital: When there is access to business credit in the area and also accompanied by assistance, it will increase the motivation of farmers to pay more attention to the sustainability of the oil palm farming system. In this 
case, oil palm plasma farmers in Sungai Lilin District, Musi Banyuasin Regency are included in the moderate criteria with a score of 2 because there are many business partners, training and coaching from oil palm companies such as PT. Hindoli, and agricultural counseling from the Plantation Service and assistance from the Oil Palm Plantation Cooperative (KPKS) in Sungai Lilin District, Musi Banyuasin Regency.

Indicators of land productivity, financial income/profit (R/C ratio): When land productivity increases, financial benefits will increase, so it is expected that farmers will try to improve the quality of oil palm. In this indicator, oil palm plasma smallholders in Sungai Lilin District, Musi Banyuasin Regency are included in the low criteria with a score of 1 because according to the researchers' calculations the average income of oil palm plasma smallholders in Sungai Lilin District, Musi Banyuasin Regency is IDR. 6,899,141.95 per cultivated area per year. Meanwhile, the Musi Banyuasin Regency Government, South Sumatra, has set the 2021 district minimum wage (UMK) at IDR. 3,251,832 per month.

According to Soekartawi in Simamora (2015) the difference between the gross income of the farm and the total expenditure of the farm is called the net income of the farm. Farming net income measures the rewards obtained by farming families from the use of factors of production work, management and own capital or loan capital invested in farming, therefore net income is a measure of farm profits that can be used to compare several farm performances. Net income is obtained by subtracting the total revenue from the total cost of smallholder oil palm farming in Sungai Lilin District, Musi Banyuasin Regency from September 2020 to August 2021.

Table 3 - Farming IncomeOil Palm Plasma Farmers in Sungai Lilin District, Musi Banyuasin Regency, 2020-2021

\begin{tabular}{|c|c|c|c|c|}
\hline No. & Description & Quantity (Unit/Year) & Price/Unit/Year (IDR) & Total per Year (IDR) \\
\hline A. & Total cost & & & $25,688,297.51$ \\
\hline \multirow[t]{6}{*}{1.} & Tool depreciation cost & & & 945,000 \\
\hline & - Dodos & 1 & 80,000 & 80,000 \\
\hline & - Gancu & 1 & 14,000 & 14,000 \\
\hline & - Bucket & 3 & 15,000 & 45,000 \\
\hline & - Handsprayer & 2 & 400,000 & 800,000 \\
\hline & - $\quad$ Measuring Bowl & 3 & 2,000 & 6,000 \\
\hline \multirow[t]{7}{*}{2.} & Variable Cost & & & $16,066,228.99$ \\
\hline & • $\quad$ Seedling (Tree) & 259 & 43,000 & $11,155,513.89$ \\
\hline & - $\quad$ Urea Fertilizer (kg) & 207 & 2800 & $581,124.44$ \\
\hline & - $\quad$ TSP-36 Fertilizer (kg) & 233 & 8.000 & $1,867,900,000$ \\
\hline & - $\mathrm{KCl}$ Fertilizer $(\mathrm{kg})$ & 259 & 10,200 & $2,646,191.67$ \\
\hline & - Dolomite Fertilizer (kg) & 259 & 1.060 & 274.996 .39 \\
\hline & - Herbicide (I) & 392 & 62,500 & 340.502 .60 \\
\hline \multirow[t]{7}{*}{3.} & Labor cost (HOK) & & & $8,677,068.52$ \\
\hline & - Planting & & & $389,145,89$ \\
\hline & - $\quad$ Fertilization $3 x$ & & & $420,000.00$ \\
\hline & - $\quad$ HPT spraying $3 x$ & & & $255,000.00$ \\
\hline & - $\quad$ Trim Midrib $3 x$ & & & $3,035,337.50$ \\
\hline & - $\quad$ Transport FFB & & & $3,3600,000.00$ \\
\hline & - KUD maintenance & & & $1,217,585.63$ \\
\hline B. & Production (Kg/Lg/Year) & & & $16,444.09$ \\
\hline C. & Selling Price $(\mathrm{Rp} / \mathrm{kg})$ & & & 1981.71 \\
\hline D. & Revenue (Rp/Lg/Year) & & & $32,587,439.46$ \\
\hline E. & Income (Rp/Lg/Year) & & & $6,899,141.95$ \\
\hline
\end{tabular}

Source: Primary data processed (2021).

Based on table 3 it is known that fixed costs incurred by plasma farmers are calculated using the depreciation method, which is the farmer's expenses for buying equipment, deducted by the salvage value (selling price) then divided by the economic life of the equipment. The equipment used in the form of Dodos, Gancu, Bucket, Handsprayer and Dosing Bowl. These five tools are the tools most widely used by plasma farmers in the harvesting process according to the age of the oil palm plant in Sungai Lilin District, Musi Banyuasin Regency.

This Dodos tool is used by farmers during the harvesting process, because in general 
this tool is to help release fresh fruit bunches (FFB) from oil palm trunks. Dodos are usually only used for oil palm plantations that are still low or around the age of oil palm plants $<10$ years because dodos are not too long, to see in more detail the depreciation costs of dodos can be seen in table 3. Usually every plasma farmer in a year has one Dodos tool with the price or depreciation charge is around IDR. 80,000 with a percentage of 8.46 percent per year.

Furthermore, gancu, this tool is usually used to help make it easier for farmers in terms of transporting fresh fruit bunches (FFB) into transport trucks, gancu is also made of iron with a curved shape. Finally, the Angkong, the average farmer has a rickshaw to transport the fresh fruit bunches (FFB) that have been harvested to the harvesting site (TPH). However, farmers usually rarely use rickshaws and prefer to use motorbikes because they are faster and do not spend a lot of energy. Usually every plasma farmer in a year has one hook tool with a depreciation cost or cost of around IDR. 14,000 with a percentage of 1.48 percent per year. The buckets are usually used to collect fallen or loose FFB and to be used for other oil palm management such as fertilization or watering. At least plasma farmers have 3 buckets per year with a depreciation cost of IDR. 45,000 with a percentage of 4.76 percent per year.

Then the Handsprayer machine is usually used by plasma farmers about 2 pieces per arable area per year with a depreciation cost of IDR. 800,000 with a percentage of 84.65 percent per year. Finally, the dosing bowl is used by plasma farmers to calculate the amount of fertilizer to be distributed to oil palm plantations. At least plasma farmers have 3 measuring cups for each fertilizer used with a depreciation cost of IDR 6,000 with a percentage of 0.65 percent per year.

Conclusions based on field results, most of the plasma farmers do not have complete farming tools and only a few have these farming tools. This is because the entire process of maintenance to harvest is carried out by farm laborers who are assisted by cooperatives and their respective group leaders.

In this study, variable costs are costs incurred in one production. The variable costs consist of fertilizer costs, herbicide costs and labor costs (wages). This variable cost greatly affects the expenditure and income of oil palm plasma smallholders in Sungai Lilin District, Musi Banyuasin Regency. The components included in the variable cost category of oil palm plasma farmers in Sungai Lilin District, Musi Banyuasin Regency, namely the cost of seeds, urea fertilizer, TSP-36 fertilizer, KCL fertilizer, dolomite fertilizer, herbicide was the largest variable costs amounted to IDR. 16,066,228.99, namely the cost of purchasing certified superior seeds of the Simalungun type and 570 at a cost of IDR. 11,155,513.89. per hectar per year with an average arable area of about 2 hectares per smallholder oil palm.

In terms of labor, oil palm plasma smallholders in Sungai Lilin District, Musi Banyuasin Regency generally use workers from outside the family. Because these plasma farmers are partnering with PT Hindoli through a cooperative, activities such as fertilizing, spraying, trimming midribs and harvesting are left to the cooperative management and farmer groups. So that there are no respondents who use labor from within their own families because most of the family members of plasma farmers do not want to work as farmers and prefer to work outside of farming. In general, there are 2-5 workers who carry out farming activities on a wholesale basis. The average total labor cost (HOK) per arable area per year is IDR. $8,677,068.52$ per cultivated area per year. The components of labor costs include wages for planting, fertilizing, spraying HPT, trimming fronds, transporting FFB and maintaining KUD. With the largest cost of $\mathrm{Rp}$. 3,360,000 per arable area per year from the component of wages for transporting FFB at the time of oil palm harvest.

Revenue is the result of production obtained by farmers multiplied by the price of fresh fruit bunches (FFB) each month. Meanwhile, income is the difference between the amount of income received by farmers and production costs incurred by plasma farmers, both variable and fixed costs in farming activities. The average production obtained by oil palm farmers in Sungai Lilin District, Musi Banyuasin Regency in 2020-2021, which is $16,444.09 \mathrm{~kg}$, is included in the low production category because the age of oil palm is still around 3 years, just replanting and only producing about 1 year. Furthermore, it has not yet entered the productive age of oil palm. The average price of TBS in 2020-2021 is around IDR. 1,981.71, 
and the amount of revenue that is IDR. 32,587,439, 46 per cultivated area per year after deducting the total cost, the net income of oil palm plasma smallholders is IDR. 6,899,141.95 per cultivated area per year.

\section{CONCLUSION}

Based on the results of the research that has been done, it can be concluded that the level of sustainability in the economic dimension is on the moderate criteria. However, in terms of land productivity indicators, income or financial benefits $(\mathrm{R} / \mathrm{C}$ ratio) are at a low level because according to the researchers' calculations, the average income of smallholder oil palm farmers in Sungai Lilin District, Musi Banyuasin Regency is IDR. 6,899,141.95 per cultivated area per year. Meanwhile, the Musi Banyuasin Regency Government, South Sumatra, has set the 2021 district minimum wage (UMK) at IDR. 3,251,832 per person per month. Therefore, it can be concluded that the income of oil palm plasma farmers in Sungai Lilin District, Musi Banyuasin Regency is still low below the district minimum wage because the age of oil palm is about 3 years and does not include the productive age of oil palm consequently the production and income of oil palm plasma farmers in Sungai Lilin Subdistrict Musi Banyuasin Regency are still in the low category. As for suggestions that can be conveyed based on the research that has been carried out, such as in determining discount fees and prices for plasma farmers, it is better to always hold a meeting first, so that the details of the funds made by the cooperative management and farmer groups are clear details and can be understood by farmers.

\section{REFERENCES}

1. Adams M, Ghaly AE. 2007. An integral framework for sustainability assessment in agro-industries: Application to The Costa Rican Coffee Industry International Journal of Sustainable Development and World Ecology13:83-102.

2. Arikunto. 2002. Research Methodology A Proposal Approach. PT. Rineka Cipta. Jakarta.

3. Central Bureau of Statistics. 2020. Musi Banyuasin Regency in Figures 2020. Central Statistics Agency of South Sumatra.

4. Central Bureau of Statistics. 2020. South Sumatra Province in Figures 2017. ISNN: 2356-4172. Central Bureau of Statistics of Musi Banyuasin Regency.

5. Central Bureau of Statistics. 2019. Statistics of Indonesian Oil Palm 2017. Subdirectorate of Plantation Crops Statistics. CV. Dharmaputra.

6. Demiyati T. Budi WP 2013. Feasibility Analysis of Smallholder Oil Palm Plantation Investment with Profit Sharing System in Budi Asih Village, Tungkal llir District, Banyuasin Regency, South Sumatra. Agribusiness forums. Published by: Master Sciences of Agribusiness Program IPB in Bollaboration with Agribuisness Association of Indonesia. Volume 3, No. 1.

7. Directorate General of Plantation. 2015. Demand for Palm Oil. Directorate General of Plantation, Jakarta.

8. International Institute for Sustainable Development. 2014. The State of Sustainability Initiatives Review. Canada.

9. Ministry of Agriculture. 2016. Outlook Coffee: Agricultural Commodities Plantation Subsector. Center for Agricultural Data and Information Systems Secretariat General of the Ministry of Agriculture. Jakarta.

10. Muharani L, ddk. 2020. Evaluation of Smallholder Oil Palm Plantation Sustainability in Tidal Lowlands of Pulau Rimau Sub-District of Banyuasin Regency. Journal of Suboptimal Lands. Vol. 9, No.1: 80-88.

11. Nababan, BO, Yesi, DS, and Maman, H. 2007. Analysis of the Sustainability of SmallScale Capture Fisheries in Tegal District, Central Java (RAPFISH Approach Technique). Journal of Marine and Fisheries Policy and Socio-Economic Research. Marine and Fisheries Research Agency. 2(2): 137-158. 
12. Ngadi, Noveria M. 2017. The sustainability of oil palm plantations in Indonesia and prospects for development in border areas. Indonesian Society Journal. 43(1): 95-111.

13. Novita, Suryaningrat, Andriani, and Widyotomo. 2012. Analysis of the Sustainability of the People's Coffee Plantation Business Area (KUPK) in Sidomulyo Village, Jember Regency. Journal of Agritech. Vol. 32 No. 2 online May 2012.

14. Peattie, K, \& Crane, A. (2005). Green marketing: Legend, Myth, farce or prophesy Qualitative Market Research. International Journal 8: 357-370.

15. Pusdatin (Center for Agricultural Data and Information), 2016. Outlook for Palm Oil in the Plantation Subsector. ISSN 1907-1507. Secretariat General - Ministry of Agriculture.

16. Rospiani, Destiya. 2018."Analysis of Changes in Prices of Fresh Fruit Bunches (FFB) on Household Income of Plasma Farmers in Fulfilling Decent Living Needs (KHL) in Sungai Lilin District, Musi Banyuasin Regency. Thesis. Indralaya: Sriwijaya University.

17. Sjarkowi F. 2018. Processing of Farming VS Agribusiness "Policy Strategy and Business Management Strengthening State Economic Fundamentals". ISBN 97996207-1-6. CV. Kaffah Satria Usaha.

18. Soekarno. 1995. Farming Analysis. Jakarta: University of Indonesia.

19. Sriati. 2012. Social Research Methods. Palembang: Sriwijaya University.

20. UNESCO. (2004). United Nations decade of education for sustainable development. Retrieved March 13, 2007, from http://portal.unesco.org/education/en/en/ in Going beyond Green: The "Why and How" of Integrating Sustainability into the Marketing Curriculum. 